\title{
Quality: the Jurassic Park experience
}

\author{
Tony Henry
}

Grant shook his head. "Its been discussed, in the field. Many people imagined it was coming. But not so soon."

"Story of our species," Malcolm said, laughing. "Everybody knows it's coming but not so soon."

Two years ago I had occasion to visit my father in hospital. At the entrance to the ward there was a policy statement about quality which talked of the holistic nature of patient care and the need for empathy with relatives and friends. It described how the patient was the epicentre of all activity. The staff on the ward were as frosty as the day and the mood in the ward was one of misery. My father later moved to another ward where there was no statement about quality but an air of happiness and purposefulness. As I sat by my father's bed the man in the next bed asked for a cup of tea. There was some gentle banter about not being the proper time for tea, and the man ended the exchange by saying that it was, after all, his birthday. Within two minutes he had a cup of tea, a piece of cake with a candle in it, and a homemade birthday card signed by four of the nurses.

\section{Business culture}

Colleges of further education became independent corporations on 1 April 1993. This independence has given them responsibility for their own success or failure; previously they were part of local authorities and were dependent on them, now they are very much on their own.

The new "business culture" is pervading further education. Some of my colleagues are turning into accountants overnight. Where we used to have discussions about delighting students we now talk about virement and bottom lines. It is understandable for colleagues to think that the budget has replaced the curriculum at the centre of everything we do. They may think of tight computer information systems giving real-time data to inform the decision making process. They may envisage that all small and uneconomic groups are closed. They may think that they have no longer any responsibilities to their communities. They may think that delegated budgets lead to "hard" establishments which have no concern for students or the people who work in them.

Such views are wrong for colleges operating in the newly independent sector, and they are an inaccurate view of most successful businesses in 1993. Tom Peters, the American business evangelist, reminds us that studens will never say of a college: "It's got a great budget." No student has ever come to East
Birmingham because we balance our books. Students do not come to us because we have the 62nd lowest unit of resource of any college in England and Wales. They come to us because of caring staff who help to make them successful in achieving what they want and happy while the process occurs.

The work of Peters has proved seminal in the quality and service drive of the new business culture and it, together with the works of Deming and Joiner, ${ }^{2}$ provide the theoretical background to total quality at this college. The philosophy is also backed by the 2000 year old Tao of Lao $\mathrm{Tsu}^{3}$ and current work which is being done in fractals (best described by Malcolm in Furassic Park). ${ }^{1}$

\section{Successful characteristics}

Peters ${ }^{4-6}$ has tried to determine the traits of America's most successful companies. They are in the main:

- Closeness to the customer

- Productivity through people

- Autonomy and entrepreneurship

- Constant innovation

- Belief in teamwork.

If we begin to apply some of these philosophies to the world of education and health care I am sure that many advances in quality can be made. For example, the lessons of customer care currently being followed by British Airways, the high street banks, Mothercare, McDonalds and others need to be learnt by us in the public sector.

Closeness to the customer means putting our students and patients at the centre of everything we do. Without students the college may well be a quieter and cleaner place: our administrative systems could cope without their constant demands, life would be so much more ordered, and we would all be without a job.

Productivity through people is another central element of the excellence design strategy. Staffing accounts for about $70 \%$ of a college's budget. It is essential that the staff understand and act on the corporate goals; they require training and retraining. They are the most important resource in an educational establishment. They must be listened to, looked after, and loved. It is they who are the closest to our customers; they are responsible

\section{Staff are the front line}

for customer care: they are the front line. How much training has the average college receptionist had in the past two years? When was the last quality improvement training 
programme organised for the establishment's cleaning staff? Do all staff know the significance of customer care? Love, cherishing, caring, and passion are terms which do not come easily to most British managers, but they are terms which are in everyday use in industry and commerce in Japan: we must not be afraid of the soft side of leadership.

Autonomy and entrepreneurship within the organisation have to be encouraged. The leadership of the college must be prepared to tolerate or even encourage failures.

Innovation and improvement have to be the mission of the organisation. This innovation again lies with the people in the front line. They are encouraged to work in teams and quality circles. They are given time off work to improve constantly the service or product to existing and potential customers.

Belief in teamwork - At East Birmingham all lecturers and support staff have reduced timetables to allow them to attend course team meetings on Friday mornings. These meetings are the quality development drivers for the college; they are more important than any management meetings or subcommittee of the Academic Board.

What we have therefore are "soft" organisations: the budget is secondary; people are the primary resource of production; students are at the heart of everything we do; computers and management information free people to be creative rather than replace people.

The quality improvement circle (figure) is central to the ethos of the college. Deming was chosen as the college quality guru for several reasons, but one stands out in particular. Juran stated that $85 \%$ of everything that was wrong with an organisation was the fault of management; Deming changed that figure to 92 per cent! "Workers," he said, "worked in the system while managers worked on the system".

\section{BS 5750 and total quality management: the only options?}

Faced with uncertainty, under-resourcing, and being unloved, organisations of further education have been led to believe that there are two alternative solutions - namely, BS 5750 and total quality management (TQM). I would like to disagree. Firstly, I do not see BS 5750 and TQM as alternatives. An organisation can be aiming for TQM and using BS 5750 as a

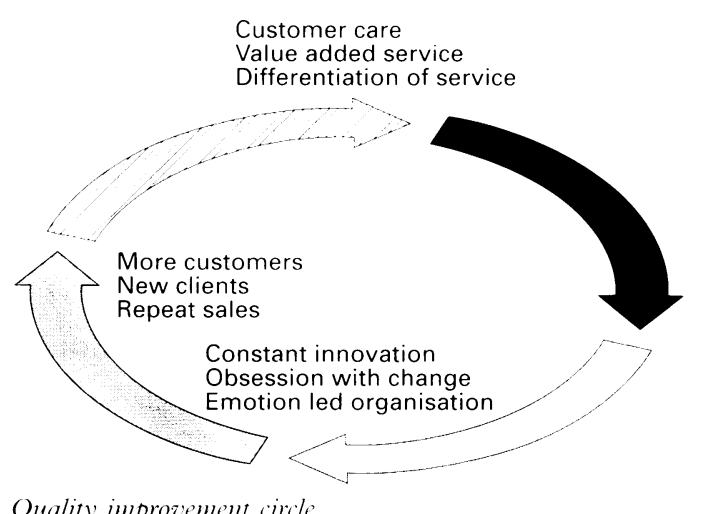

vehicle for achieving it - the standard can be a useful milestone rather than the millstone it is usually portrayed. Secondly, I have heard representatives of organisations saying: "Oh, we're not interested in BS 5750, we're going for TQM." When questioned further, they have a naive view of TQM, which is based on smiling at everyone and copping out on much of the hard groundwork to systems which has to be undertaken. Thirdly, I think there are other systems of achieving quality. It is interesting that neither of East Birmingham's major clients, Land Rover and the Birmingham Training and Enterprise Council (TEC), are demanding the college to obtain BS 5750 . The decision to adopt BS 5750 was taken internally by the college for a number of reasons. Both clients have their own systems of ensuring quality through second and third party assessment in which East Birmingham's system sits comfortably. The TEC's code of practice model, in which all parties are involved in drawing up sector-based codes of practice to ensure quality is a very exciting development and one in which the college plays a full part. The system ensures ownership of the quality system and moves away from a top down, imposed model of quality assurance. The point I am trying to make is that quality in an organisation is either there or it isn't. It cannot be brought into an organisation through BS 5750 or TQM. What those systems can do is to protect quality and develop quality; if quality exists in an organisation it will be identified by whatever quality assurance systems are devised.

Organisations are becoming more like fractals, and we have to have new ways of approaching them and measuring them. The following lines from furassic Park mav give us a clue to what is in store:

- At the carliest drawing of the fractal curve, few clues to the underlying mathematical structure will be seen.

- With subsequent drawings of the fractal curve sudden changes may appear.

- Details appear more clearly as the fractal curve is redrawn.

- Inevitably, underlying instabilities begin to appear.

- Flaws in the svstem will now become severe.

- System recovery may prove impossible

- Increasingly the mathematics will demand the courage to face its implications.

Quality is about customer delight rather than customer satisfaction. It is about total staff involvement rather than hierarchical top down system imposition. It is about incremental quality improvement rather than giant leaps. It is about living, loving, passion, fighting, cherishing, nurturing, struggling, crying, laughing.

Crichton .M. Fltassic Park. Hutchinson, 1991.

Joiner Associates. A practical approach to quality. Madison, Wisconsin: Joiner Associates, 1985

Heider J. The tao of leadcrship. Aldershot: Wildwood House, 1986

Peters 1, Austin N. In sicarch of excellence. Lessons for America's best rum compantes. Hanger and Row, 1982.

Peters 1. Thrieing on ihas: Handbook for management reciolution. Pan, 1987.

Peters T. Libiration management. Pan, 1993.

Deming WE. Out of the crivis. Cambridge, Massachusetts: Massachusetts Institute of Technology, 1986. 